\title{
Prevotella/Streptococcus and other anaerobes colonize the metagenome (nasopharyngeal swab) submitted by Emory University School of Medicine, Georgia in Covid19 patient, corroborating the hypothesis that SARS-Cov2 is enabling anaerobes
}

Sandeep Chakraborty

\section{Letter}

The hypothesis [1] that SARS-Cov2 [2,3] enables anaerobic bacteria (Prevotella, et al) to colonize the lungs disrupting homeostasis finds resonance in the 'forgotten disease' Lemierre's Syndrome [4-9,9, 10]. Lemierre's Syndrome is also caused by anaerobic bacteria enabled by Epstein Barr Virus [11,12]. Symptoms common to both diseases include ARDS, septic shock, blood clots and arterial stroke [?,13-17]. Covid19 starts from the lungs (possibly making it easier to treat), in contrast to Lemierre's Syndrome that originates in the jugular vein.

\section{Nasopharyngeal swab(Accid:SRR11829376)}

Here, metagenome from a Covid19 patient in Emory University School of Medicine, Georgia is analyzed (Table 1, Fig 1). Prevotella/Streptococcus and other anaerobes colonize the metagenome, corroborating the hypothesis that SARS-Cov2 is enabling anaerobes [1]. The bacterial load is quite high, the first five species comprise $70 \%$ of the load.

\section{Atopobium - a biofilm producing bacteria implicated in bacterial vaginosis (BV)}

The Bangladesh metagenome had a new hard-to-culture anaerobe implicated in disease - Lawsonella [1]. Here, Atopobium [18,19] is another anaerobe with significant abundance ((Table 1, Fig 1). Atopobium is implicated in bacterial vaginosis and 'around $80 \%$ of the cases and might be involved in therapeutic failure' [20]. BV biofilm formation, and antibiotic resistant A. vaginae could explain therapeutic failures and recurrences of BV [19]. Long drawn symptoms in Covid19 have caused great consternation, and could be similarly explained by persistance of biofilms [21]. Also, the synergy between Atopobium and Gardnerella Vaginalis is a key virulence factor implicated in disease, since G. vaginalis displaces protective lactobacill, and the initial colonization [22] establishes the biofilm structures to which secondary colonisers, such as A. vaginae attach.

\section{Gut metagenome (Accid:SRR11827437)}

Another sample shows Enterococcus colonization, and although the source of the sample is mentioned as nasopharyngeal swab, most of the bacteria are gut related (Table 2). 


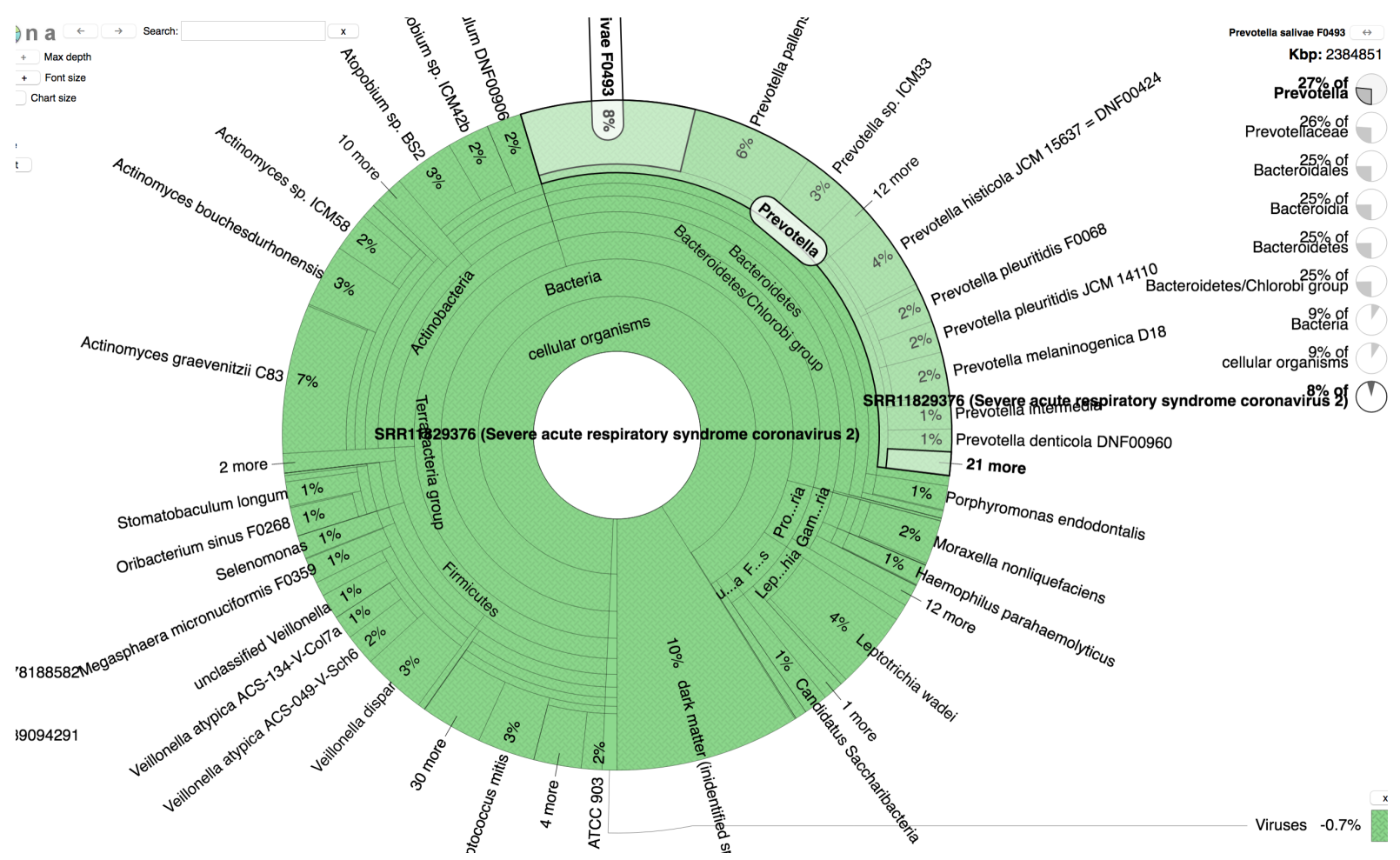

Figure 1: Krona figure generated from the NCBI analysis: The Prevotella abundance is visible (light green). Atopobium (5\%) of the reads is around 11 o'clock. 
Table 1: Bacterial reads in sequencing data (nasopharyngeal swab) of submitted by Emory University School of Medicine, Georgia Prevotella/Streptococcus and other anaerobes colonize the metagenome, corroborating the hypothesis that SARS-Cov2 is enabling anaerobes. The bacterial load is quite high, the first five species comprise $70 \%$ of the load. FAC-ANE=facultatively anaerobic (aerobic, but capable of switching to fermentation if oxygen is absent).

\begin{tabular}{|c|c|c|c|}
\hline PerMillion & Bacteria & Type & Diseases \\
\hline 218827 & Veillonella & obligateanaerobic & rare cases of meningitis, osteomyelitis, and periodontal disease [23] \\
202862 & Prevotella & obligateanaerobic & aspiration pneumonia, lung abscess, pulmonary empyema, etc [24,25] \\
191362 & Streptococcus & FAC-ANE & pneumonia, bacteremia [26] \\
66431 & Schaalia & FAC-ANE & similar to Actinomyces, alimentary tract diseases [27] \\
33327 & Atopobium & anaerobic & Bacterial vaginosis [20] \\
23896 & Leptotrichia & FAC-ANE & Endocarditis [28] \\
23534 & Moraxella & aerobic & otitis media in infants and children [29] \\
15448 & Bacteroides & obligateanaerobic & 'genus Bacteroides have the most antibiotic resistance mechanisms' [30] \\
12172 & Actinomyces & FAC-ANE & alimentary tract diseases [27] \\
9603 & Megasphaera & obligateanaerobic & Bacterial Vaginosis [31,32] \\
8482 & Porphyromonas & obligateanaerobic & periodontal disease [33] \\
7103 & Campylobacter & aerobic & diarrhoea [34] \\
6706 & Fusobacterium & obligateanaerobic & periodontal disease [36] \\
6689 & Selenomonas & obligateanaerobic & new genus [37] \\
4793 & Lachnoanaerobaculum & anaerobic & periodontal, tonsillitis, peritonsillar abscess, etc [35] \\
\hline \hline
\end{tabular}


Table 2: Bacterial reads in sequencing data, most likely from the gut, submitted by Emory University School of Medicine, Georgia: Although the source of the sample is mentioned as nasopharyngeal swab, most of the bacteria are gut related. Here, Enterococcus, which can be pathogenic, is seen to be colonizing. FAC-ANE=facultatively anaerobic (aerobic, but capable of switching to fermentation if oxygen is absent).

\begin{tabular}{|c|c|c|c|}
\hline PerMillion & Bacteria & Type & Diseases \\
\hline 104097 & Enterococcus & FAC-ANE & urinary tract infections; intraabdominal [38] \\
\hline 8612 & Escherichia & FAC-ANE & cholecystitis, bacteremia, cholangitis, urinary tract infection [39] \\
\hline 6383 & Corynebacterium & aerobic & diphtheria toxin $[40]$ \\
\hline 3888 & Klebsiella & FACANE & pneumoni [41] and intestinal colonization [42] \\
\hline 3307 & Salmonella & FAC-ANE & typhoid $[43]$ \\
\hline 2968 & Shigella & FAC-ANE & eading cause of diarrhoeal death among children [44] \\
\hline 1365 & Dolosigranulum & FAC-ANE & multiple sclerosis $[45]$ \\
\hline 787 & Staphylococcus & FAC-ANE & Boils, impetigo, food poisoning, cellulitis, and toxic shock syndrome \\
\hline 593 & Carnobacterium & anaerobic & frequently isolated from natural environments and foods [46] \\
\hline 545 & Bacillus & FAC-ANE & Inhalation or respiratory anthrax \\
\hline 414 & Lactobacillus & FACANE & mutualistic beneficial relationship with the human body, [47] \\
\hline 317 & Streptococcus & FAC-ANE & pneumonia, bacteremia $[26]$ \\
\hline 313 & Aerococcus & aerobic & Urinary tract infection [48] \\
\hline 310 & Erwinia & FAC-ANE & dermohypodermitis and bactaeremia [49] \\
\hline 286 & Sphingomonas & aerobic & causative agent of infection in immunocompromised patients [50] \\
\hline
\end{tabular}




\section{References}

1. Chakraborty S (2020). Sars-cov2 enables anaerobic bacteria (Prevotella, et al) to colonize the lungs disrupting homeostasis - symptoms (ARDS, septic shock, blood clots, arterial stroke) finds resonance, with key differences, in the 'forgotten disease' Lemierre syndrome, caused by anaerobic bacteria enabled by Epstein Barr virus. doi:10.31219/osf.io/usztn. URL osf .io/usztn.

2. Perlman S (2020). Another decade, another coronavirus.

3. Wu F, Zhao S, Yu B, Chen Y, Wang W, et al. (2020) Complete genome characterisation of a novel coronavirus associated with severe human respiratory disease in Wuhan. China bioRxiv 24.

4. Potter M, Drysdale H, Price P, Buck A (1988) Disseminated intravascular coagulation with fusobacterium necrophorum septicaemia. Postgraduate medical journal 64: 155-156.

5. Page Y, Comtet C, Tardy B, Zeni F, Thevenet D, et al. (1990) Disseminated intravascular coagulation in fusobacterium necrophorum septicemia. Scandinavian journal of infectious diseases 22: $743-747$.

6. Hagelskjaer L, Prag J, Malczynski J, Kristensen J (1998) Incidence and clinical epidemiology of necrobacillosis, including lemierre's syndrome, in denmark 1990-1995. European journal of clinical microbiology and infectious diseases 17: 561-565.

7. Hlibczuk V (2007) Lemierre's syndrome complicating bacterial pharyngitis in a patient with undiagnosed factor xii deficiency. The Journal of emergency medicine 32: 365-369.

8. Khan A, Ganesan S, Arora M, Hussain N (2013) Life threatening complication of sore throat: Lemierre's syndrome. The Indian Journal of Pediatrics 80: 1059-1061.

9. Rae J, Misselbrook K (2017) Lemierre's syndrome-a rare cause of disseminated sepsis requiring multiorgan support. Journal of the Intensive Care Society 18: 329-333.

10. Surapaneni BK, Omar H, Iguina MM, Suarez M (2020) Fusobacterium necrophorum septicemia leading to lemierre's syndrome in an immunocompetent individual: A case report. Cureus 12.

11. Boz G, Iskender S, Caylan R, Aydin K, Koksal I (2005) A case of lemierre's syndrome following epstein-barr virus infection. Anaerobe 11: 185-187.

12. Chacko E, Krilov L, Patten W, Lee P (2010) Lemierre's and lemierre's-like syndromes in association with infectious mononucleosis. The Journal of Laryngology \& Otology 124: 1257-1262.

13. Thachil J, Tang N, Gando S, Falanga A, Cattaneo M, et al. (2020) Isth interim guidance on recognition and management of coagulopathy in covid-19. Journal of Thrombosis and Haemostasis .

14. Tang N, Li D, Wang X, Sun Z (2020) Abnormal coagulation parameters are associated with poor prognosis in patients with novel coronavirus pneumonia. Journal of Thrombosis and Haemostasis .

15. Cui S, Chen S, Li X, Liu S, Wang F (2020) Prevalence of venous thromboembolism in patients with severe novel coronavirus pneumonia. Journal of Thrombosis and Haemostasis .

16. Kollias A, Kyriakoulis KG, Dimakakos E, Poulakou G, Stergiou GS, et al. (2020) Thromboembolic risk and anticoagulant therapy in covid-19 patients: Emerging evidence and call for action. British Journal of Haematology .

17. Leisman DE, Deutschman CS, Legrand M Facing covid-19 in the icu: vascular dysfunction, thrombosis, and dysregulated inflammation. Intensive Care Medicine : 1. 
18. Jovita MR, Collins MD, Sjödén B, Falsen E (1999) Characterization of a novel atopobium isolate from the human vagina: description of atopobium vaginae sp. nov. International Journal of Systematic and Evolutionary Microbiology 49: 1573-1576.

19. Mendling W, Palmeira-de Oliveira A, Biber S, Prasauskas V (2019) An update on the role of atopobium vaginae in bacterial vaginosis: what to consider when choosing a treatment? a mini review. Archives of gynecology and obstetrics : 1-6.

20. Polatti F (2012) Bacterial vaginosis, atopobium vaginae and nifuratel. Current clinical pharmacology 7: $36-40$.

21. Chen L, Wen Ym (2011) The role of bacterial biofilm in persistent infections and control strategies. International journal of oral science 3: 66-73.

22. Alves P, Castro J, Sousa C, Cereija TB, Cerca N (2014) Gardnerella vaginalis outcompetes 29 other bacterial species isolated from patients with bacterial vaginosis, using in an in vitro biofilm formation model. The Journal of infectious diseases 210: 593-596.

23. Bhatti MA, Frank MO (2000) Veillonella parvula meningitis: case report and review of veillonella infections. Clinical infectious diseases 31: 839-840.

24. Nagaoka K, Yanagihara K, Morinaga Y, Nakamura S, Harada T, et al. (2014) Prevotella intermedia induces severe bacteremic pneumococcal pneumonia in mice with upregulated platelet-activating factor receptor expression. Infection and immunity 82: 587-593.

25. Larsen JM (2017) The immune response to Prevotella bacteria in chronic inflammatory disease. Immunology 151: 363-374.

26. Cunningham MW (2000) Pathogenesis of group a streptococcal infections. Clinical microbiology reviews 13: 470-511.

27. Li J, Li Y, Zhou Y, Wang C, Wu B, et al. (2018) Actinomyces and alimentary tract diseases: A review of its biological functions and pathology. BioMed research international 2018.

28. Matias WR, Bourque DL, Niwano T, Onderdonk AB, Katz JT (2016) Subacute bacterial endocarditis with Leptotrichia goodfellowii in a patient with a valvular allograft: a case report and review of the literature. Case reports in infectious diseases 2016.

29. Goldstein EJ, Murphy TF, Parameswaran GI (2009) Moraxella catarrhalis, a human respiratory tract pathogen. Clinical Infectious Diseases 49: 124-131.

30. Wexler HM (2007) Bacteroides: the good, the bad, and the nitty-gritty. Clinical microbiology reviews 20: $593-621$.

31. Marrazzo JM, Fiedler TL, Srinivasan S, Thomas KK, Liu C, et al. (2012) Extravaginal reservoirs of vaginal bacteria as risk factors for incident bacterial vaginosis. The Journal of infectious diseases 205 : $1580-1588$.

32. Lanjekar V, Marathe N, Ramana VV, Shouche Y, Ranade D (2014) Megasphaera indica sp. nov., an obligate anaerobic bacteria isolated from human faeces. International journal of systematic and evolutionary microbiology 64: 2250-2256.

33. Diaz PI, Slakeski N, Reynolds EC, Morona R, Rogers AH, et al. (2006) Role of oxyr in the oral anaerobe Porphyromonas gingivalis. Journal of bacteriology 188: 2454-2462. 
34. Lindblom GB, Sjögren E, Hansson-Westerberg J, Kaijser B (1995) Campylobacter upsaliensis, C. sputorum sputorum and C. concisus as common causes of diarrhoea in Swedish children. Scandinavian journal of infectious diseases 27: 187-188.

35. Han YW (2015) Fusobacterium nucleatum: a commensal-turned pathogen. Current opinion in microbiology 23: 141-147.

36. Gonçalves LF, Fermiano D, Feres M, Figueiredo LC, Teles FR, et al. (2012) Levels of Selenomonas species in generalized aggressive periodontitis. Journal of periodontal research 47: 711-718.

37. Hedberg ME, Moore ER, Svensson-Stadler L, Hörstedt P, Baranov V, et al. (2012) Lachnoanaerobaculum gen. nov., a new genus in the lachnospiraceae: characterization of lachnoanaerobaculum umeaense gen. nov., sp. nov., isolated from the human small intestine, and lachnoanaerobaculum orale sp. nov., isolated from saliva, and reclassification of eubacterium saburreum (prévot 1966) holdeman and moore 1970 as lachnoanaerobaculum saburreum comb. nov. International journal of systematic and evolutionary microbiology 62: 2685 .

38. Murray BE (1990) The life and times of the enterococcus. Clinical microbiology reviews 3: 46-65.

39. DuPont HL, Formal SB, Hornick RB, Snyder MJ, Libonati JP, et al. (1971) Pathogenesis of escherichia coli diarrhea. New England Journal of Medicine 285: 1-9.

40. Murphy JR (1996) Corynebacterium diphtheriae. In: Medical Microbiology. 4th edition, University of Texas Medical Branch at Galveston.

41. Diancourt L, Passet V, Verhoef J, Grimont PA, Brisse S (2005) Multilocus sequence typing of klebsiella pneumoniae nosocomial isolates. Journal of clinical microbiology 43: 4178-4182.

42. SELDEN R, Lee S, Wang WLL, BENNETT JV, EICKHOFF TC (1971) Nosocomial klebsiella infections: intestinal colonization as a reservoir. Annals of Internal Medicine 74: 657-664.

43. Gal-Mor O, Boyle EC, Grassl GA (2014) Same species, different diseases: how and why typhoidal and non-typhoidal salmonella enterica serovars differ. Frontiers in microbiology 5: 391.

44. Tickell KD, Brander RL, Atlas HE, Pernica JM, Walson JL, et al. (2017) Identification and management of shigella infection in children with diarrhoea: a systematic review and meta-analysis. The Lancet Global Health 5: e1235-e1248.

45. Jorge FM (2014) The potential pathogenicity of Dolosigranulum pigrum in multiple sclerosis, and the occurrence of the organism in the upper respiratory tract .

46. Leisner JJ, Laursen BG, Prévost H, Drider D, Dalgaard P (2007) Carnobacterium: positive and negative effects in the environment and in foods. FEMS microbiology reviews 31: 592-613.

47. Sherid M, Samo S, Sulaiman S, Husein H, Sifuentes H, et al. (2016) Liver abscess and bacteremia caused by lactobacillus: role of probiotics? case report and review of the literature. BMC gastroenterology 16: 138 .

48. Rasmussen M (2016) Aerococcus: an increasingly acknowledged human pathogen. Clinical Microbiology and Infection 22: 22-27.

49. Prod'homme M, Micol L, Weitsch S, Gassend JL, Martinet O, et al. (2017) Cutaneous infection and bactaeremia caused by erwinia billingiae: a case report. New microbes and new infections 19: 134-136.

50. Bayram N, Devrim I, Apa H, Gulfidan G, Turkyilmaz HN, et al. (2013) Sphingomonas paucimobilis infections in children: 24 case reports. Mediterranean journal of hematology and infectious diseases 5 . 